\title{
„Plavšić smijenio Kršnjavija” - Hrvatsko društvo umjetnosti na prijelomnici 1918./1919. godine
}

Kraševac, Irena

Source / Izvornik: Institucije povijesti umjetnosti : zbornik 4. kongresa hrvatskih povjesničara umjetnosti, 2019, 267 - 276

Conference paper / Rad u zborniku

Publication status / Verzija rada: Published version / Objavljena verzija rada (izdavačev PDF)

https://doi.org/10.31664/z4khpu.35

Permanent link / Trajna poveznica: https://urn.nsk.hr/urn:nbn:hr:254:525462

Rights / Prava: Attribution 4.0 International/Imenovanje 4.0 međunarodna

Download date / Datum preuzimanja: 2023-04-26

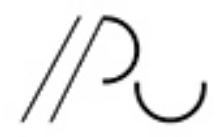

INSIIIUTZZA POVIJESTUMJETNOSI
Repository / Repozitorij:

PODEST - Institute of Art History Repository

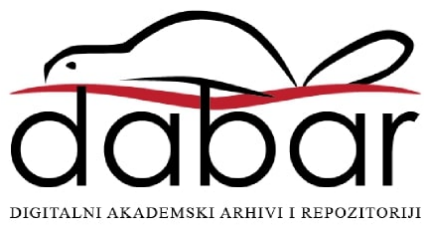




\section{„Plavšić smijenio Kršnjavija"-Hrvatsko društvo umjetnosti na prijelomnici ıgı8./ıgıg. godine}

\section{Irena Kraševac}

Institut za povijest umjetnosti, Zagreb ikrasevac@ipu.hr

https://orcid.org/oooo-ooo2-0494-3757
U hrvatskoj su se povijesti 20. stoljeća ključne prijelomnice događale u ratnim godinama, koje su donijele i smjene političkih sistema i vlasti, a potom inicirale radikalne promjene na svim razinama društvenog djelovanja, pa tako i u kulturnim institucijama. Po završetku Prvoga svjetskog rata Hrvatsko društvo umjetnosti također je dočekalo burnu i radikalnu smjenu vlasti. Nakon što je pedeset godina Iso Kršnjavi aktivno djelovao u Društvu, od I868. godine kao njegov inicijator i osnivač, potom kao dugogodišnji tajnik i potpredsjednik, a od I9o3. do I9ı8. kao predsjednik, smijenio ga je Dušan Plavšić. Dok su Kršnjavijev lik i djelo u međuvremenu prilično dobro istraženi i obrađeni, ponajprije zahvaljujući radu Olge Maruševski, a u novije doba na simpoziju Iso Kršnjavi-veliki utemeljitelj i pripadnom zborniku, ${ }^{1}$ njegov nastavljač dosad nije dobio dovoljno pozornosti u hrvatskoj historiografiji, pa ni u povijesti umjetnosti. Povjesničarka Mira Kolar pridala je pozornost Plavšiću u članku u kojem se isključivo bavi njegovom poslovnom karijerom u financijskim institucijama u kojima je radio. ${ }^{2}$

Dušan Plavšić (Vinkovci, I875.-Zagreb, I965.; sl. I), po zanimanju pravnik i bankar, a po vokaciji likovni i književni kritičar, vodio je Društvo umjetnosti od I9I8. do ig27. godine, kada ga je zamijenio arhitekt i zagrebački (grado)načelnik Vjekoslav Heinzel. ${ }^{3}$ Izborom Plavšića Društvo je dobilo predsjednika iz potpuno različite profesije, premda je bio aktivan sudionik razdoblja hrvatske moderne na prijelazu ig. u 20. stoljeće, kao osnivač i vlasnik časopisa Mladost, suradnik časopisa Život, blizak suradnik i prijatelj brojnih umjetnika okupljenih u „secesijskom” Društvu hrvatskih umjetnika i organizator izložbe hrvatske umjetnosti u okviru Austro-Ugarske Monarhije u Sankt Peterburgu I899. godine. ${ }^{4}$

Dušan Plavšić rođen je u jednoj od najpoznatijih i najimućnijih osječkih obitelji. Njegov otac Nikola Anastasije Plavšić bio je dugogodišnji tajnik osječke Trgovačko-obrtničke komore, ${ }^{5}$ koji omogućuje sinu studij u Beču, što je ostavilo snažan trag
I OLGA MARUŠEvSKI, Iso Kršnjavi kao graditelj, Zagreb, Društvo povjesničara umjetnosti Hrvatske, I986. (prvo izdanje) i Zagreb, Institut za povijest umjetnosti, 20og. (drugo izdanje); ista, Društvo umjetnosti I868.- -1879.- I94I., Zagreb, Društvo povjesničara umjetnosti Hrvatske, 2004.; Iso Kršnjavi-veliki utemeljitelj, Zbornik znanstvenog skupa, (ur.) Ivana Mance i Zlatko Matijević, Zagreb, Hrvatski institut za povijest i Institut za povijest umjetnosti, 2015 .

2 Poslovnu karijeru Plavšić je započeo u Sarajevu Igor. na mjestu tajnika Bosansko-hercegovačke privilegirane zemaljske banke. Godine ıgo6. dolazi u Zagreb i postaje tajnikom Prve hrvatske štedionice, a od I9I2. do I9I9. ravnatelj je zagrebačke podružnice Hrvatske zemaljske banke d.d. iz Osijeka; zahvaljujući njegovu posredovanju osnivaju se brojna industrijska i trgovačka poduzeća u Hrvatskoj, čiji je Plavšić dioničar. Od I9ı9. predsjednik je i Zagrebačke burze, a početkom I922. osnovao je Balkansku banku d.d., u koju kapital ulažu brojni hrvatski veleposjednici, a koja će zbog političkih smicalica propasti. Kao pristaša unitarne jugoslavenske ideje Dušan Plavšić je bio posrednik preko kojega su hrvatske institucije nakon I9ı8. preuzimale jugoslavensko, unitarističko obilježje. Tako Hrvatsko-slavonska zemaljska banka u Osijeku postaje Jugoslavenska banka, Hrvatska dionička tiskara prelazi u ruke Jugoštampe, časopis Hrvatska njiva I92o. mijenja ime u Jugoslavenska njiva, a i Hrvatsko društvo umjetnosti ostaje bez nacionalne odrednice. Godine I92I. Plavšić postaje glavni ravnatelj Jugoslavenske banke d.d., a u travnju I922. postaje pomoćnik ministra financija $u$ Beogradu („mijenja krune u dinare”). U Beogradu se nije dugo zadržao jer nije bio u milosti kralja Aleksandra i ministra financija, srpskog radikala Milana Stojadinovića, te se vraća u Zagreb. Od I934 do I939. komesar je Prve hrvatske štedionice. Stalno oscilirajući između bankarstva, industrije i turizma, Plavšić je zaradio popriličan imetak, ali i naposljetku bankrotirao. Vidi: MIRA KOLAR, Buran život dr. Dušana Plavšića (I875.-I965.), u: Osječki zbornik, 24-25 (I998.- I999.), I3I-I44.

3 Istraživanje o Dušanu Plavšiću obuhvatilo je arhivske fondove u Hrvatskom državnom arhivu: HRHDA-I979., Hrvatsko društvo likovnih umjetnika i HR-HDA-757, Obitelj Plavšić.

4 IRENA KRAŠEVAC, ŽELJKA TONKOVIĆ, Umjetničko umrežavanje putem izložaba u razdoblju rane moderne-sudjelovanje hrvatskih umjetnika na međunarodnim izložbama od ı89ı. do ıgoo. godine, $\mathrm{u}$ : Radovi Instituta za povijest umjetnosti, 40 (20I6.), $203^{-2 I} 7$. 


\section{Slika I}

Dušan Plavšić

Fototeka Muzeja grada Zagreba

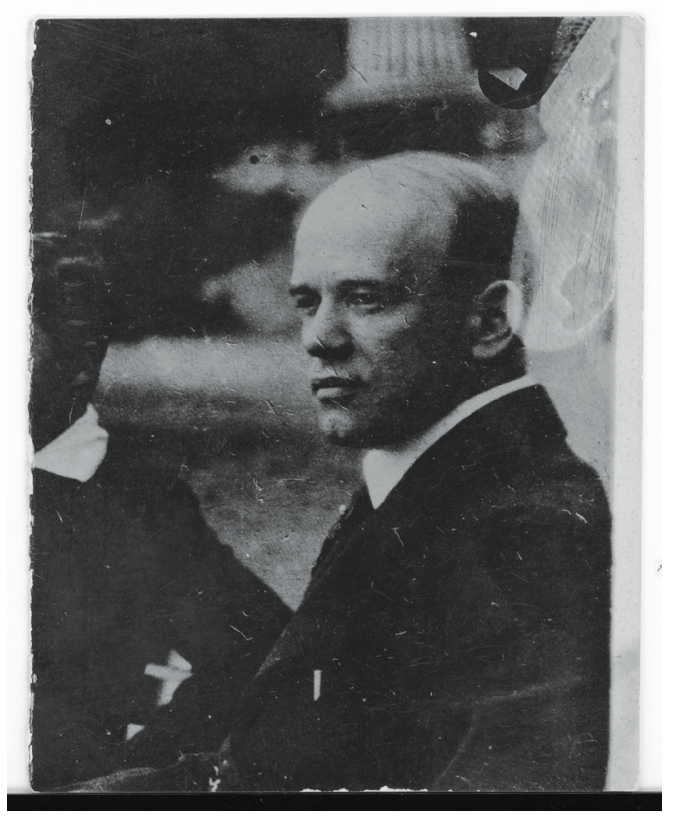

u formiranju mladog intelektualca. U Beču se uključuje u rad Hrvatskog akademičkog društva Zvonimir, koje je bilo nositelj studentskog pokreta izvan Hrvatske, a u čijim Pravilima stoji da je osnovano „s ciljem duševne naobrazbe i društvene zabave svojih članova, te da se svaka politika isključuje". Pravi članovi mogu biti samo „hrvatski đaci bečkih visokih škola” i „mogu biti članovi sve dok ne polože svoje ispite”. ${ }^{6}$ Hrvatskih je sveučilištaraca u Beču u posljednjem desetljeću ig. stoljeća bilo dovoljno za stvaranje kritične skupine koja je nastojala priključiti hrvatsku kulturu modernim zbivanjima i postati jednim od ključnih čimbenika razvoja hrvatske moderne umjetnosti i književnosti. Uz Plavšića, u Beču su u to vrijeme Ivo Pilar, Milivoj Dežman i Iso Velikanović te Robert Frangeš, Rudolf Vadlec, Tomislav Krizman i Ivan Meštrović.

Nakon studija u Beču i kratkog boravka u Pragu I899., Plavšić rgor. godine odlazi u Sarajevo, gdje ubrzo također okuplja intelektualnu, umjetničku i književnu elitu, a zahvaljujući rodbinskim vezama dolazi u najuži kontakt sa Silvijem Strahimirom Kranjčevićem, jer su Plavšićeva supruga Mila i Kranjčevićeva Ela sestre. ${ }^{7}$ I u Sarajevu slijedi svoju vokaciju likovnog kritičara i postaje suradnikom časopisa Nada koji Kranjčević uređuje, a s Ivom Pilarom pokreće osnivanje Hrvatskog kluba ${ }^{8}$ te pokušava uspostaviti kulturne veze između Zagreba i Sarajeva zalažući se za organiziranje prve izložbe hrvatskih umjetnika I9o4. godine, koja na kraju nije realizirana. Prema Plavšićevim tvrdnjama, razlog treba tražiti u činjenici da se hrvatski umjetnici nisu htjeli izdvajati nakon prve jugoslavenske izložbe održane u Beogradu iste godine, kako se ne bi „oslabio dojam te izložbe” i jer su „beogradski dvor i bogati privatnici pokupovali mahom sve bolje radove hrvatskih umjetnika". ${ }^{9}$

Godine I9o6. postaje tajnik Prve hrvatske štedionice, pa ravnatelj Hrvatske zemaljske banke; s obitelji se nastanjuje se
5 U autobiografskom zapisu Plavšić je napisao da je „rođen 23. travnja I875. u Vinkovcima od oca Nikole Plavšića, pravoslavne vjere, rođenog u Bršadinu, zavičajnog u Osijeku, gdje je kao tajnik Trgovačko-obrtničke komore u Osijeku umro I9I2. godine, i majke Ljudmile rođ. pl. Ilić, rimo-katoličke vjere, rođene u Zagrebu kao potomka stare hrvatske plemićke obitelji a umrle godine ı89.." Citat prema tekstu „Zagreb, I94I: Dušan Plavšić o sebi”, objavljenu kao prilog io u knjizi: STANISLAV MARIJANOVIĆ, Fin de siècle hrvatske moderne. Generacija „mladih” i časopis „Mladost”, Osijek, I99o., I76-I77; također vidi: HR-HDA-757, Obitelj Plavšić, kut. 37, Plavšić o sebi, rukopis.

6 HR-HDA-757, Obitelj Plavšić, kut. 42, Pravila Hrvatskog akademičkog družtua „Zvonimir”, primjerak iz osobnog vlasništva „Dušana Nikolajeva Plavšića, stud. phil.".

7 U braku s Milom Kašaj rođeno je troje djece; u Sarajevu su rođeni sinovi Čedomil (Igo2.) i Dušan ml. (I904.), a kći Silvana rođena je Igı2. u Zagrebu. Nakon rane smrti Kranjčevićevih, bračni par Plavšić usvaja njihovu kćer Višnju. Braća Plavšić i Višnja Kranjčević kao zagrebački gimnazijalci osnovali su I922. godine avangardnu umjetničku skupinu Traveleri (od eng. travelers), kojoj je poslije ime promijenjeno u Mladi zenitisti, i čiji je član bio i Josip Seissel (zenitistički pseudonim: Jo Klek), poslije suprug Silvane Plavšić. Mjesto sastajanja bila im je kućica u vrtu Plavšićeve vile u Rokovoj 9. https://hr.wikipedia.org/wiki/Traveleri (posjećeno I7. travnja 20I8.)

8 O odnosu Plavšića i Ive Pilara vidi: STJEPAN MATKOVIĆ, Pilarova pisma Dušanu Plavšiću: fragment poznavanja hrvatskih secesionista, u: Godišnjak Pilar, 2 (2002.), 33-40, I59-I67. Autor donosi transkripte sedam Pilarovih pisama upućenih Dušanu Plavšiću I897. i I898. godine, koja su pohranjena u Nacionalnoj i sveučilišnoj knjižnici i Hrvatskom državnom arhivu. Glavni cilj Pilara i Plavšića bilo je utjecati na kulturna i umjetnička kretanja u skladu s duhom vremena, pod izrazitim utjecajem bečke moderne.

9 HR-HDA-757, Obitelj Plavšić, kut. 28, Historijat osujećene izložbe u Sarajevu i još koješta, što je s tim u savezu, I904., rukopis Dušana Plavšića. Prvi dogovor oko izložbe pao je u vrijeme boravka Milivoja Dežmana i Ivana Tišova u Sarajevu, inicijativu je preuzelo Hrvatsko pjevačko prosvjetno društvo „Trebević”, Plavšić je oformio priređivački odbor s predsjednikom Ćirom Truhelkom, dok je on preuzeo tajništvo, a izložba se trebala organizirati u prostoru dvorane sarajevske Beledije. Izložbu je osujetilo održavanje Kongresa jugoslavenske omladine u Beogradu tijekom kojeg je organizirana I. jugoslavenska umjetnička izložba, te se dopremanje sekcije hrvatskih umjetnika iz Beograda u Sarajevo nije moglo realizirati. Plavšićeva pisma Milivoju Dežmanu čuvaju se u Institutu za književnost HAZU. O izložbi u Beogradu v.: RADINA vUČETIĆ, Jugoslavenstvo u umjetnosti i kulturi-od zavodljivog mita do okrutne realnosti (Jugoslavenske izložbe I9o4.-I940.), u: Časopis za suvremenu povijest, 3 (2009.), 70I-7I4, 703-705. 
u Zagrebu, ${ }^{10}$ a njegovo ime nalazimo na popisima članova Društva umjetnosti I9II. i I9I3. godine..1 Uz poslovno-bankarsku, gradio je i usporednu karijeru likovnog i književnog kritičara te kolekcionara umjetnina, koja ga je blisko povezala s hrvatskim umjetnicima, pa u konačnici i dovela do položaja predsjednika Društva umjetnosti nakon Kršnjavija.

Plavšićevo rano zanimanje za likovnu umjetnost i književnost potiče ga na pokretanje časopisa Mladost, smotre za modernu književnost i umjetnost, koji izdaje zajedno s Guidom Jenyjem. Časopis uređuju u Beču, a tiskaju u tipografskom zavodu u Zagrebu. Sveukupno je objavljeno šest svezaka (brojeva) tijekom I897. i I898., i premda kratka daha, sadržajem i oblikovanjem ostavio je dubok trag u formiranju hrvatske moderne. ${ }^{12}$

Plavšić se javlja kao likovni kritičar i izvjestitelj i u drugom važnom časopisu hrvatske moderne, Život, urednika Milivoja Dežmana, koji je u svega dvije godine izlaženja, ıgoo. i ıgoı., objavio nekoliko njegovih tekstova i umrežio ga u krug hrvatskih umjetnika-secesionista, koji se I897. odvajaju od Kršnjavijeva Društva umjetnosti i osnivaju Društvo hrvatskih umjetnika na čelu s Vlahom Bukovcem. Plavšić sudjeluje u organizaciji Prvoga hrvatskog salona, kojim je otvoren Umjetnički paviljon u Zagrebu, i podupire izdanje istoimene publikacije I898., a sljedeće I899. godine Bukovac ga, uz Rudolfa Valdeca, imenuje tajnikom hrvatskoga dijela austro-ugarske izložbe u Sankt Peterburgu, koju organizira tamošnje Društvo likovnih umjetnika ${ }^{13}$. O izložbi je i opširno pisao u članku „Hrvatska umjetnost u Petrogradu”, objavljenu u časopisu Život, dok je u petrogradskoj reviji objavio studiju o hrvatskoj umjetnosti. ${ }^{14}$ Njegova nastojanja da se o hrvatskim umjetnicima i izložbama piše u onodobnom stranom tisku dovela su ga u kontakt s poznatim bečkim kritičarem Ludwigom Hevesijem, čije je pismo također sačuvano u Plavšićevoj ostavštini ${ }^{15}$ (sl. 2, 3).

Ovo kratko podsjećanje na ranog Plavšića i njegov udjel $u$ formiranju hrvatske moderne umjetnosti i suradnju s likovnim umjetnicima bilo je važno kako bismo razumjeli njegovo preuzimanje Hrvatskoga društva umjetnosti igı 8. godine. Kršnjavi je, naime, naslutio da se sprema „velika zavjera” te je u dnevniku zabilježio kronologiju događanja. „20. studenoga I9I7. Robert Frangeš i Mixich s jedne strane, Kerdić s druge, dr Artur Schneider i Viktor Kovačić s treće strane urotili su se u namjeri da me sruše. Dr Schneider je mobiliziro slobodne zidare i poveo akciju s njihovim najagilnijim članom, bankovnim direktorom Plavšićem.”" „26. studenoga I9I7. Generalna skupština Društva umjetnika održana je 25. II. Od upisanih 200 članova stiglo ih je otpriliko ıoo; ostali su stari članovi. Prilikom glasanja smo ja i odbor, što sam ga predložio, dobili I45 glasova. Protivnici su uložili protest protiv izbora što ga je potpisalo 86 nazočnih. U ime opozicije što je nasrnula na mene govorio je Dušan Plavšić, jedan od najvatrenijih slobodnih zidara. Protiv mene i odbora održao je pravi optužbeni govor." ${ }^{17}$ Arhivski dokumenti potvrđuju autentičnost toga navoda. Dušan Plavšić uzeo je riječ i obrušio se na rad dosadašnjeg odbora te tražio da „glavna skupština predloženi izvještaj tajnika i blagajnika ne uzme do znanja i da se predsjedniku i upravnom odboru
Io Na temelju pisama možemo pratiti Plavšićeve zagrebačke adrese: Trg Franje Josipa 3, Rokova ul. 9 (vila građena po projektu Brune Bauera), Jurjevska 55 Demetrova 5, Masarykova 24/I. Posjedovao je i vilu u Novom Vinodolskom, gdje je ljetovao između dvaju ratova.

II HR-HDA-I979, HDLU, kut. 4, Popis članova „Društva umjetnosti”. God. I9ı. Pod brojem I23: „Plavšić Dušan, bankov. činovnik, pravi član, Zagreb”; na istom mjestu, Godišnje izvješće Hrvatskog društva umjetnosti za godinu MCMXII, I9I3., Popis članova H.D.U. Pod brojem I79: „Dušan Plavšić, ravnatelj banke, pravi član”.

I2 STANISLAV MARIJANOVIĆ (bilj. 5).

I3 HR-HDA-757, Obitelj Plavšić, kut. I7, Korespondencija sa slikarima, Bukovčevo pismo s memorandumom i žigom Društva hrvatskih umjetnika. Cit.: „Nous dannons le plein pouvoir a nos secretaires N. M. Plavšić et Valdec de disposer de nos œvres d'art envoyées a l'exposition de St. Pétérsbourg. La socété des artistes Croates, Zagreb le 4 novembre I899, Le president: Vlaho Bukovac". Vidi i: IRENA KRAŠEVAC, ŽELJKA TONKOVIĆ (bilj. 4).

I4 DUŠAN PLAVŠIĆ, Petrogradska izložba, u: Život, I, 5 (I9oo.), I4I-I45; isti, Rusko društvo prenosnih izložaba umjetnosti, u: Život, I, 6, (I9oo.), 202-205 HR-HDA-757, Obitelj Plavšić, kut. 44 i 49, Iskustvo hudožestvenaja promyšlenost, rukopis. Izložbu je priredilo Carsko društvo za unapređenje umjetnosti (Société impériale d'encouragements des beaux-arts), koje je djelovalo od ı820. do I929. godine. https://en.wikipedia.org/wiki/Imperial_Society_for_ the_Encouragement_of_the_Arts (posjećeno I7. travnja 20I8.).

I5 HR-HDA-757, Obitelj Plavšić, kut. 44, Pismo Ludwiga Hevesija od 29. siječnja [s. a.]. Vjerojatno je posrijedi I899. ili ıgoo. jer je u pismu riječ o izložbi u Sankt Peterburgu. Plavšić mu se valjda obratio kako bi napisao kritički osvrt o hrvatskim umjetnicima za ruski časopis Art et Industrie. Hevesi zahvaljuje na tome, ali se ispričava nedostatkom vremena. $\mathrm{O}$ hrvatskoj umjetnosti ima dobro mišljenje još od peštanske Milenijske izložbe. Pismo je pisano rukom, njemačkom goticom, na memorandum-papiru časopisa Fremden-Blatt, za koji je Hevesi pisao. Zahvaljujem kolegici Ani Petrović na transkripciji pisma.

I6 ISO KRŠNJAVI, Zapisci iza kulisa hrvatske politike, (prir.) Ivan Krtalić, Zagreb, Mladost, I986., sv. 2, 788.

I7 Isto, 79ı. Slobodno zidarstvo Dušanova oca, Nikole Plavšića, sačuvano je u cjelini: bilješke izlaganja, pozivnice za sastanke lože, tiskovine, glasila i brošure o masoneriji te korespondencija u sklopu arhivskog gradiva. Vidi: HR-HDA-757, Obitelj Plavšić. 


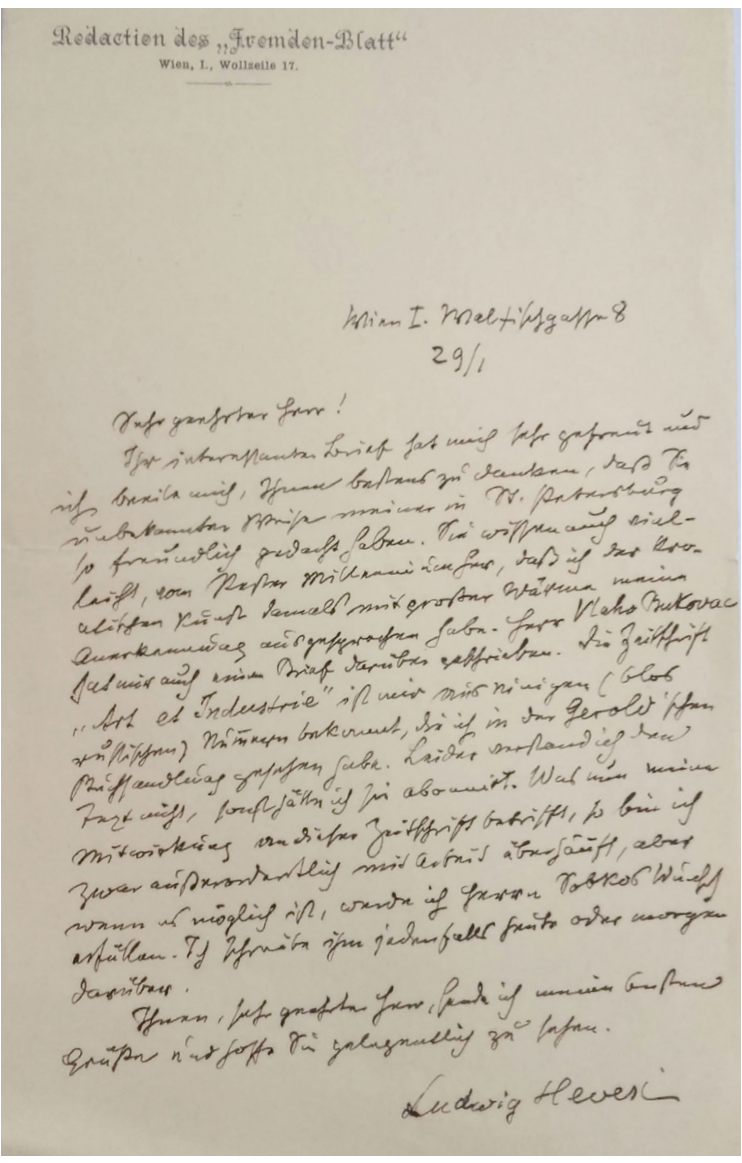

Redaction des „Fremden-Blatt” Wien, I. Wollzeile I7

\section{Wien I. Walfischgasse 8 $29 / 1$}

Sehr geehrter Herr!

Ihr interessanter Brief hat mich sehr gefreut und ich beeile mich, Ihnen bestens zu danken, daß Sie unbekannter Weise meiner in St. Petersburg so freundlich gedacht haben. Sie wissen auch vielleicht, vom Pester Millennium her, daß ich der kroatischen Kunst damals mit großer Wärme meine Anerkennung ausgesprochen habe. Herr Vlaho Bukovac hat mir auch einen Brief darüber geschrieben. Die Zeitschrift "Art et Industrie” ist mir aus einigen (bloß russischen) Nummern bekannt, die ich in der Gerold'schen Buchhandlung gesehen habe. Leider verstand ich den Text nicht, sonst hätte ich sie abonniert. Was nun meine Mitwirkung an dieser Zeitschrift betrifft, so bin ich zwar außerordentlich mit Arbeit überhauft, aber wann es möglich ist, werde ich Herrn Sobkos Wunsch erfüllen. Ich schreibe ihm jedenfalls heute oder morgen darüber. Ihnen, sehr geehrter Herr, sende ich meine besten Grüßen und hoffe Sie gelegentlich zu sehen.

Ludwig Hevesi
Slika 2

Pismo Ludwiga Hevesija

Dušanu Plavšiću

Hrvatski državni arhiv

\section{Slika 3}

Transkripcija pisma Ludwiga

Hevesija Dušanu Plavšiću

transkripcija: Ana Petrović 
izrazi nepovjerenje". ${ }^{18}$ Ipak, nakon provedena glasanja izabrani su sa I45 glasova Kršnjavi kao predsjednik te odbornici: Robert Auer, G. Baldauf, Janko Barle, Ivan Bojničić, Herman Bollé, Gjuro Arnold, Ljudevit Ivančan, Ferdo Kovačević, Rudolf Lubinski, I. Draganec, V. Krišković, L. Radičević, D. vitez Trnski, D. Taborski, Maksimilijan Vanka i Robert Frangeš. ${ }^{19}$ Agonija u Društvu time se prolongirala na sljedeću godinu, a Kršnjavi je u međuvremenu postao svjestan da se mora povući, što je dostojanstveno učinio dopisom adresiranim na potpredsjednika, u svome stilu s mnogo ironije i sarkazma: ${ }^{20}$

\section{U Zagrebu 3I/X 9I8.}

Presuijetli gospodine!

Dan ujedinjenja i slobode domovine osvanuo je a već sviću dani njezine veličine i sjaja.

Izgubili smo bili nadu, da ćemo ikada doživiti takovu sreću. Tim je veća naša radost. Upravo nam se čini da još sanjamo.

Novo doba nosi nove zadaće. Valjati će Hrvatsko Društvo Umjetnosti staviti na nove temelje, da postane žarištem ne samo za hrvatsku nego i za cijelu jugoslavensku umjetnost.

Nove zadaće zahtijevaju nove ljude.

Odlučio sam zato, da se odreknem predsjedništva i odborništva

H.D.U., što Vama kao podpredsjedniku jauljam.

$S$ velepoštovanjem

Dr Iso Kršnjavi

Time je otvoren put za sazivanje izvanredne glavne skupštine

I5. prosinca I9ı8., na koju se odazvalo šezdeset redovitih članova, a od prijašnjeg odbora nije bio prisutan ni jedan član. Nakon provedena glasanja, pri čemu se biralo između Plavšića i dr. Vladimira baruna Turkovića, odabran je Odbor u sastavu: Dušan Plavšić, predsjednik; te kao članovi Ljubo Babić ml., arh. Bruno Bauer, Salomon Berger, Stjepan Boranić, prof. Bela Csikos Sesia, prof. Ferdo Goglia, Mirko Hermann, Ivo Kerdić, Ferdo Kovačević, arh. Viktor Kovačić, Tomislav Krizman, Lato pl. Mihalović, Jerolim Miše, arh. Edo Schön, prof. Gjuro Szabo, dr. Branko Šenoa, Vladimir Tkalčić, Maksimilijan Vanka, prof. Rudolf Valdec, Anton Ullrich. ${ }^{21}$

Sljedeća glavna skupština održana je I5. lipnja r9ı9. godine, a iz Zapisnika ${ }^{22}$ saznajemo da su joj prisustvovala trideset i tri redovita člana, predsjednik Dušan Plavšić, tajnik Vladimir Tkalčić, blagajnik Salomon Berger te odbornici Ferdo Kovačević, Ljubo Babić, Viktor Kovačić i Ferdo Goglia, Robert Frangeš i Ernest Schulz kao verifikatori (ovjerovitelji zapisnika) te članovi Ignjat Fischer, Karlo Spiller, Andrija Milčinović, Viktor Hoffiler, Josip Bužan, Robert Jean [Ivanović], između ostalih. Uz izvještaj o blagajničkom poslovanju (koje je „po revizorima pregledano i u redu pronadjeno"), Plavšić iznosi problem vezan uz „teške prilike i poteškoće povezane s novčanim saniranjem bivšeg odbora kojim je društvo oštećeno", nakon čega Tkalčić čita i „izvještaj revizionalnog odbora”, koji prikazuje da se članarine nisu redovito uplaćivale te iznosi problem s troškovima izrade Kerdićeve plakete, koju je „Kršnjavi samovlasno zaplijenio, a da društvu troškove nije nadoknadio". ${ }^{23}$ Predsjednik
I8 HR-HDA-I979, HDLU, kut. 2, Govor Dušana Plavšića. Plavšić predbacuje mali broj članova, nesudjelovanje Društva u najvažnijim umjetničkim događajima u zadnjim godinama (primjerice, izložbe Proljetnog salona, Meštrovića i Račkog, Maksimilijana Vanke i Kraljevića, nemar oko publiciranja monografija naših umjetnika, npr. Mašića i Bukovca, te kataloga „naše galerije slika” [Moderne galerije], „koja nije popularizirana ni stručno obradjena”. Spominje „aferu Kršnjavi-Kerdić” te postavlja pitanje „tko je snosio troškove za tu plaketu". Kritizira nemar oko crkvene umjetnosti i starih crkvenih spomenika, neuključivanje Društva u podizanje spomenika palim junacima te da Društvo nije ništa poduzelo da se kod spomenika „pokojnom našem kralju (...) pripazi na umjetničku stranu i da se kod toga zaposluju naši domaći umjetnici" [spomenik Franji Josipu I., op.a.].

I9 HR-HDA-I979, HDLU, kut. 2, Zapisnik Generalne skupštine.

20 HR-HDA-I979- HDLU, kut. 2, Ostavka Ise Kršnjavija. Potpredsjednik je $u$ to vrijeme bio njegov dugogodišnji suradnik i tajnik Društva, Ivan Bojničić.

2I Prijepis prema glasačkom listiću-tiskanici. HRHDA-I979, HDLU, kut. 2 i HR-HDA-757, Obitelj Plavšić, kut. 47 .

22 HR-HDA-I979, HDLU, kut. 2, Zapisnik glavne skupštine Društva umjetnosti održane I5. lipnja IgIg. Također vidi: Govor predsjednika Dušana Plavšića na glavnoj skupštini, Izvještaj o radu Društva, u: Sauremenik, I4, 7-8 (I9ig.), 38I-383, 395-398.

23 Kipar i medaljer Ivo Kerdić bio je zamoljen da u povodu sedamdesetog rođendana izradi Kršnjavijevu portretnu medalju, koju je Kršnjavi odbio jer nije bio zadovoljan prikazom svoga lika u profilu. O skandalu i sudbini medalje vidi: IVAN MIRNIK, Izidor Kršnjavi i Ivo Kerdić, u: Iso Kršnjavi-veliki utemeljitelj (bilj. I), 384-392. 
Plavšić izvješćuje da je Društvo oštećeno za 3424 kruna i 44 filira te pita Skupštinu „da li se (...) imade bivši predsjednik Kršnjavi pozvati, da društvu nanesenu štetu nadoknadi ili imade li se taj iznos kao gubitak otpisati." Prijedlog arhitekta Ignjata Fischera, da se društvo „u nikaki dalnji proces ne upusti” te „da se nanesena šteta otpiše", prihvaćen je većinom glasova. ${ }^{24}$

U drugoj točki dnevnog reda Plavšić predlaže „da se naslov društva promijeni u prijašnji naziv 'Društvo umjetnosti' da se time raskine ograničenje regionalnog značenja društva i društvu omogući da svoj rad proširi na čitavo naše kraljevstvo". I taj je prijedlog prihvaćen te se razvila diskusija o promjenama „pojedinih $\S \S$ pravila”, da bi se prihvatile „predložene promjene i stilističke izpravke". Potom se trebao odabrati i novi odbor, na što je Ignjat Fischer predložio da se „per aclamationem izabere listina koju će (stari odbor) predložiti, a koja u glavnome na ponovni izbor predlaže dosadanje odbornike", što je jednoglasno prihvaćeno. ${ }^{25} \mathrm{U}$ daljnjoj raspravi postavljeno je pitanje knjižnice Društva, za koju je predloženo da se „priklopi knjižnici umjetničke škole". ${ }^{26}$ Kipar Robert Jean [Ivanović] postavlja pitanje gradnje novih atelijera za mlađe umjetnike, na što mu predsjednik odgovara da je „odbor tu zadaću već uzeo u svoj program". ${ }^{27} \mathrm{O}$ tome svjedoči činjenica je ujesen prve poslijeratne godine I9I9. osnovano Društvo za podizanje radiona i domova za mlađe umjetnike u Zagrebu, s predsjednikom Ljubom Babićem i tajnikom Robertom Jeanom Ivanovićem, dok je Plavšić izabran u glavni zbor Društva i imenovan nadzornim odbornikom. ${ }^{28}$ Osim što je postao predsjednikom Društva umjetnosti, Plavšić 29. lipnja I9I9. postaje potpredsjednik Gospodarskog odbora Matice hrvatske.

Jedna od prvih neposrednih aktivnosti nakon preuzimanja Društva bila je organizacija Jugoslavenske izložbe u Parizu u ožujku rgig. u vrijeme trajanja mirovnih pregovora, koju je inicirao Ivan Meštrović, a „koja bi manifestirala kulturno i narodno jedinstvo nas Jugoslavena". ${ }^{29}$ Plavšić se kao netom imenovan predsjednik Društva umjetnosti založio za organizaciju izložbe u nastojanju da hrvatski umjetnici sudjeluju u što većem broju. Izbor djela povjerio je „pojedinim umjetničkim korporacijama”, tako da je "grupa mlađih umjetnika (Proljetni salon)" dogovarala sudjelovanje svojih članova i izbor njihovih djela, o čemu se brinuo Krizman, dok je za "grupu starijih umjetnika (Udruženje Lada)", njihovo sudjelovanje i izbor umjetnina bio zadužen Csikos. Kao delegati koji bi pratili izložbu u Pariz imenovani su „za grupu mlađih umjetnika” Tomislav Krizman i Ljubo Babić, a „za grupu starijih umjetnika" Bela Csikos i Maksimilijan Vanka. Transport je krenuo iz Zagreba preko Sarajeva u Dubrovnik, gdje je početkom veljače petnaest sanduka s umjetninama ukrcano na brod do Francuske. U Sarajevu su priključili djela Karla Mijića i Gabrijela Jurkića, dok je „srpskih umjetnika bilo razmjerno malo zastupano, jer su uopće raztepeni po svijetu, a s druge strane našli su se nešto uvrijedjeni, što za vremena nisu bili oficijelno pozvani”, pa je kod „arangementa izložbe (trebalo) paziti na to, da njihove radnje ne budu zapostavljene, jer je nacionalno politički od velike važnosti, da se srpski umjetnici kao takovi
24 Zapisnik (bilj. 22).

25 Isto; Odabrani (i potvrđeni) su kao „Članovi odbora-radnici": Ljubo Babić ml., Bela Csikos Sesia, Ivo Kerdić, Tomislav Krizman, Ferdo Kovačević, Viktor Kovačić, Jerolim Miše, dr. Branimir Šenoa, Edo Schön, Rudolf Valdec; Članovi redoviti: Salomon Berger, dr. Gjuro Dimović, dr. Dragutin Domjanić, Ferdo Goglia, Mirko Hermann, dr. Artur Schneider, Gjuro Szabo, dr. Ivo Tartaglia, Vladimir Tkalčić, Antun Ullrich; revizori: Mirko Breyer i dr. Karlo Spiller.

26 Nejasno je da li se pritom mislilo na knjižnicu Obrtne škole ili Više škole za umjetnost i umjetni obrt.

27 Zapisnik (bilj. 22).

28 HR-HDA-757, Obitelj Plavšić, kut. I7, Dopis Društva za podizanje radiona i domova za mlađe umjetnike $u$ Zagrebu. 6. rujna I9I9. održana je skupština u salonu Ullrich u Ilici 52.

29 Ivan Meštrović je iz Berna u Švicarskoj, gdje je boravio tijekom Prvoga svjetskog rata, poslao poziv Tomislavu Krizmanu s namjerom da se organizira izložba jugoslavenske umjetnosti u Parizu. Krizman je poziv proslijedio Društvu umjetnosti, kojem je Plavšić tek postao predsjednikom, a on se založio za dalji tijek organizacije izložbe i njezino financiranje preko Povjereništva za bogoštovlje i nastavu, koje je trebalo preuzeti troškove otpreme umjetnina, njihovo osiguranje i povratak te omogućiti novčane potpore delegatima. Vidi: HR-HDA-I979, HDLU, kut. I3, dopis Društva umjetnosti Povjereništvu za bogoštovlje i nastavu od 9. siječnja I9I9. 
na toj izložbi ne osjećaju zapostavljeni” ${ }^{30}$ „Slovenci su se dosta obilno odazvali, pa su glede izložbe stupili u osobni kontakt sa g. Krizmanom, koji je sa Slovencima njihovo sudjelovanje osobno portraktirao." ${ }^{31}$ Od Bukovca, koji je u Pragu, uspjeli su dobiti ,jednu od njegovih starijih radnji”, portret gospođe Miletić, a Medoviću se nisu mogli obratiti jer se nalazi „na Kuni u kraju okupiranom po Talijanima", pa su bez njegove dozvole uzeli ,jednu njegovu sliku iz akademije”. ${ }^{2}$ Sveukupno je prikupljeno preko 280 radova hrvatskih, srpskih i slovenskih slikara i kipara, a većina radova posuđena je od Jugoslavenske akademije (JAZU) i zagrebačkoga gradskog poglavarstva te brojnih privatnih vlasnika. Pokriće troškova Jugoslavenske izložbe preuzela je (hrvatska) Zemaljska vlada u iznosu od 27.000 kruna te Narodno vijeće, koje je dotiralo 20.000 kruna. ${ }^{33}$

Plavšić je imao velika očekivanja od teizložbe, koja je trebala „dovesti do nekog ujedinjenja umjetničkog nastojanja Hrvata, Srba i Slovenaca, a napose izravnanju oprijeka između 'Proljetnog salona' i 'Lade' (...)”. ${ }^{34}$ Jedan od epiloga izložbe možemo iščitati iz pisama Društva umjetnosti Ivanu Meštroviću u Pariz, u kojem ga izvješćuju da je došlo do problema s vraćanjem eksponata jer je jedan sanduk zabunom otpremljen u Beograd, a pri pakiranju su oštećene dvije slike Mirka Račkog te po jedna Babićeva i Vankina. Također negoduje da su delegatima bile uskraćene novčane naknade. ${ }^{35}$

Druga aktivnost Društva vezana je uz natječaj koji je raspisalo Povjereništvo za prosvjetu i vjere u Hrvatskoj i Slavoniji za izradu slike Ujedinjenje Srba, Hrvata i Slovenaca, koja prikazuje oslobađanje Hrvatske od Austrije i Ugarske, te se obraća Plavšiću i Društvu za stručni sud. ${ }^{36}$ Uz Plavšića porotnici su Menci Clement Crnčić, Artur Schneider, Viktor Kovačić i Ferdo Kovačević, a skice su poslali Oton Iveković, Joso Bužan i Mato Celestin Medović.

$\mathrm{Na}$ temelju sačuvanih arhivskih dokumenata razvidno je da je Plavšić kao predsjednik Društva umjetnika održavao živu korespondenciju sa slikarima, a iz tih se pisama može razabrati da je materijalno pomagao umjetnike dajući im kredite ili otkupljujući djela za vlastitu zbirku i Modernu galeriju. Plavšiću su pisali Vladimir Becić, Bela Csikos Sesia, Konrad Filip, Robert Frangeš Mihanović, Vilko Gecan, Gabrijel Jurkić, Joza Kljaković, Mirko Rački, Jerolim Miše, Sava Šumanović, Marino Tartaglia, Đuro Tiljak, Marijan Trepše, Milivoj Uzelac, Rudolf Valdec i Tomislav Krizman. ${ }^{37}$

Kod smjene u Društvu krajem I9I8. godine evidentirana je društvena imovina u koju je spadala i Moderna galerija, „koja imade 69 djela u vrijednosti od po prilici ıoo.ooo K." ${ }^{38}$ Kao što je napomenuo u svom govoru na skupštini igr8., Plavšić je veću pažnju posvetio i problemima Moderne galerije te je već sljedeće, I9r9. godine, Ljubo Babić postavljen za „društvenog kustosa”, tj. prvog kustosa, te je sastavljen popis umjetnina u vlasništvu Društva, koji možemo smatrati jednim od prvih inventara. Zanimljiv je podatak da Plavšić posuđuje slike iz svoje zbirke za postav Moderne galerije u zgradi Muzeja za umjetnost i obrt, što smatramo njezinim prvim postavom, otvorenim u proljeće I920. godine. Djela iz Plavšićeva vlasništva možemo dijelom
30 HR-HDA-I979, HDLU, kut. I3, dopis Društva umjetnosti Ivanu Meštroviću u Pariz, [s. d.] I9ı. Uroš Predić je odbio izlagati, a Marka Murata su trebali kontaktirati pri dolasku u Dubrovnik.

$3^{\text {I }}$ Isto.

32 Isto.

33 Društvo umjetnosti u Zagrebu, u: Savremenik, I4, 7-8 (I9I9.), 395-398 (Izvještaj, 396).

34 Isto.

35 HR-HDA-I979, HDLU, kut. I3, dopis Društva umjetnosti Ivanu Meštroviću u Pariz, [s. d.] Igrg.

36 HR-HDA-757, Obitelj Plavšić, kut. 47, dopis Povjereništva za prosvjetu i vjere u Hrvatskoj i Slavoniji br. 46933 .

37 Korespondencija sa slikarima; Pisma umjetnika: Vladimir Becić, dva pisma (s. l., ožujak I92I.); Bela Csikos Sesia, jedno pismo na njemačkom jeziku (Pariz, 27. veljače r9ı9.); Konrad Filip, jedno nedatirano pismo poslano iz Münchena upućeno ocu D. Plavšića; Robert Frangeš Mihanović, tri pisma ( s. l., s. d., s. a.; s. l., 22. veljače I899.; s.l., I8. studenog I922.); Vilko Gecan, jedno pismo (Zagreb, I8. kolovoza I922.); Gabrijel Jurkić, osam pisama (Kupres, 23. srpnja I907.; Sarajevo, 2I. rujna I9Iı.; Beč, 24. siječnja I9ı2.; Sarajevo, I. travnja ı9ı6.; Sarajevo, I8. lipnja ı9ı6.; Sarajevo, 2I. lipnja I9ı6.; Sarajevo 20. studenoga, s. a.; Sarajevo, 2I. kolovoza I920.); Joza Kljaković, jedno pismo (Zagreb, I7. svibnja I920.); Mirko Rački, jedno pismo (Ženeva, 7. siječnja I920.); Jerolim Miše, jedan brzojav iz I9ı.9.; Sava Šimunović, jedno pismo bez datuma; Marino Tartaglia, jedno pismo (Orebić ıo. kolovoza I935.); Tiljak i Trepše, jedno pismo (Gruž, ıo. siječnja I920.); Milivoj Uzelac, sedam pisma iz Pariza; Rudolf Valdec, osam pisama; Tomislav Krizman, trideset i šest pisama. HR-HDA-757, Obitelj Plavšić, kut. I7.

38 Društvo umjetnosti u Zagrebu, u: Savremenik, I4, 7-8 (г9r9.), 395-398 (Izvještaj, 397); Jedan od prvih (možda i prvi) inventarnih popisa Moderne galerije nalazi se u: HR-HDA-757, Obitelj Plavšić, Moderna Galerija Društva umjetnosti. U popisu se navodi i provenijencija pojedinih umjetničkih djela, a u broju se poklapa s podatkom koji donosi tekst u Savremeniku (69 djela). 
rekonstruirati zahvaljujući sačuvanim dopisima između njega i Muzeja za umjetnost i obrt, u vezi s evidencijom umjetnina koje su bile na posudbi i pohrani u Muzeju (za Modernu galeriju) i koja Plavšić poslije potražuje. ${ }^{39} \mathrm{~S}$ pravne strane, Moderna galerija ostaje ustanovom Društva, ali se pokorava kućnom redu Muzeja. Plavšićeva zbirka umjetnina poslije je dijelom otkupljena za Modernu galeriju. ${ }^{40}$

Da se nakon nastupnoga govora punog obećanja o aktivnostima Društva koje će poduzeti nije mnogo ostvarilo, svjedoči Kršnjavijevo pismo iz I92o. u kojem kaže: „Društvo umjetnosti spava, kao što sam i predvidio, ali ne snom mrtvaca nego snom bolesnika”, ${ }^{41}$ Lunaček je u Obzoru I922. napisao „da se za Društvo umjetnosti u Zagrebu (...) ne znade da li se zove hrvatsko ili jugoslavensko, ali se znade da unatoč svojih proglasa spava (...)" ${ }^{42}$ dok je nekadašnji Plavšićev bliski prijatelj Rudolf Valdec zabilježio „kolektivnu krivicu”: „Društvo umjetnosti smo pod Plavšićem zatukli, da li će prijatelji današnje umjetnosti pod arhitektom Heinzelom uskrisiti staro Društvo umjetnosti gdje se dijele umjetnici u političke i vjerske pristalice dr. Rittiga ja to ne znam." ${ }^{43}$

U razdoblju od desetak godina nisu se održavale ni skupštine, pa je prva nakon smjene I9I8./IgI9. održana 6. ožujka ı927., a njome je predsjedao Dušan Plavšić, predsjednik u ostavci. Za „perovodju" (zapisničara) imenovan je Vladimir Tkalčić, a ovjerovitelji su Ćiril Iveković i Antun Jiroušek te Marko Rašica kao njihov zamjenik. ${ }^{44}$ Skupština je započela sjećanjem na preminule članove, Viktora Kovačića (2I. listopada I924.) i Isu Kršnjavija (3. veljače I927.). Plavšić je naglasio Kršnjavijev „veliki pozitivni rad za razvitak naše umjetnike kulture i napose Društva umjetnosti” te istaknuo „kako su postojale samo principijelne opreke a nikada lične protivštine protiv njega". Društvo umjetnosti bilo je službeno zastupano kod njegova pogreba. Svi prisutni odali su pokojniku poštovanje kličući „Slava”!45

Nadalje, Plavšić izvještava o društvenoj djelatnosti te ističe zasluge Društva za otvaranje Moderne galerije „u prikladnim prostorijama" [misli se na Muzej za umjetnost i obrt, op. a.]. Negoduje zbog činjenice da Društvo nije uspjelo postati „savjetodavni organ vlasti u svim [...] arhitektonskih pitanja itd.". Također priznaje da je „u doba pada preobrazbe državne uprave” nestalo regionalne vlasti, pa je ostalo neriješeno (financijsko) podupiranje Društva. „Izgubivši tako društvo oslon u Zagrebu, nije ga moglo naći s istih razloga ni nigdje drugdje, pa su teške poratne prilike, koje su i članovima nametale tešku borbu za opstanak skrivile, da je nastao zastoj tako, da se nije mogla ni članarina ubirati, a ta je devalvacijom krunske valute i onako postala iluzorna, pa nije dostajala ni za najpreče potrebe." 46 Uza sve poteškoće, Društvo je priredilo litografiju Ljube Babića Stara katedrala kao društvenu premiju, izdalo reprodukciju slike Isle de France Josipa Račića i započelo pripremati monografiju toga umjetnika. Plavšić izvještava o teškoj financijskoj situaciji prema kojoj je Društvo ostalo gotovo bez sredstava te je „obustavilo svoju djelatnost, nastojeći da sačuva stečeno (...) kad su prilike tražile mirovanje društvene djelatnosti". ${ }^{47}$ Nakon prihvaćanja izvještaja tajnika i blagajnika uslijedilo je
39 HR-HDA-757, Obitelj Plavšić, kut. 49, dopis Ravnateljstva Muzeja za umjetnost i obrt Dušanu Plavšiću, br. 59.-I924. od I3. studenoga I924. i dopis Dušana Plavšića ravnateljstvu Muzeja za umjetnost i obrt, od 9. studenoga I927. U dopisu Ravnateljstva Muzeja za umjetnost i obrt Plavšić se obavještava da je „ovom muzeju za izložbu u Modernoj Galeriji [povjerio] slijedeće slike, koje može u svako doba odnijeti”: I. Gecan: Ženski akt, 2. Dobrović: Portret brata /dječak drži ruku na prsima/, 3. Dobrović: Portret Baranovića, 4. Dobrović: Autoportret/u košulji/, 5. Dobrović: Venera, 6. Dobrović: Portret dame u crnom, 7. Dobrović: Portret sestre, 8. Dobrović, Portret dame, 9. Uzelac: Venera iz predgrađa, ıo. Uzelac: Sfinga, II. Iveković: Trenkovi panduri, I2. Babić: Ona, I3. Račić: Veliki ženski akt, I4 Račić: Starica, I5. Vanka: Proštenjari, s napomenom da su „sve slike uokvirene, uljene, a označene sa ceduljicom slovom 'T'. Osim toga 3 buste iz gipsa." U dopisu Dušana Plavšića od 9. studenoga I927. Plavšić Ravnateljstvu potvrđuje primitak „slika, koje su moje vlasništvo, a koje su u Modernoj galeriji bile u pohrani i na čuvanju", navodeći: I. Maksimilijan Vanka: Bistrički proštenjari, 2. Milivoj Uzelac: Venera iz predgrađa, 3. Milivoj Uzelac: Sfinga modernog grada, 4. Josip Račić: Veliki ženski akt, 5. Josip Račić: Starica kod rada, 6. Ljuba Babić: Ona, portretstudija, 7. Vilko Gecan: Ženski akt, 8. Petar Dobrović: Pjevačica šantana, 9. Isti: Portret dame u crnom, Io. Isti: Portret dame u plavom, II. Isti: Portret Baranović, I2. Isti: Moj brat, I3. Isti: Autoportret u košulji.

40 O tome je Plavšić zabilježio u trećem licu: „Koncem ratnih godina izabran je za predsjednika Hrvatskog društva umjetnosti, u kojem je svojstvu uspio konačno postaviti Modernu Galeriju i predati je javnosti. Ta galerija spada danas među prve kulturne institucije Zagreba. Za sve to vrijeme potpomagao je moralno i materijalno hrvatske književnike i umjetnike, i sakupio jednu od najpotpunijih zbirka hrvatske umjetnosti počam od Kikereca i Mašića, preko Bukovca, Medovića i drugih naših odličnih umjetnika toga vremena, od Babića, Uzelca i Meštrovića, od jedno 50 originala i oko 5 oo grafika. Od te zbirke prepustio je Plavšić kasnije općini grada Zagreba 94 komada uz minimalnu odštetu, te ta djela danas rese odjel hrvatske umjetnosti u Strossmayerovoj galeriji i u Modernoj galeriji." Cit. u: STANISLAV MARIJANOVIĆ (bilj. 5), I77 (Zagreb, I94I: Dušan Plavšić o sebi). O Plavšićevoj ulozi u i skrbi za Modernu galeriju vidi: LIBUŠE JIRSAK, Ivo Šrepel: Dokumenti, vrijeme, sudbina. Biblioteka Povijest Moderne galerije, knjiga 2, Zagreb, Moderna galerija, 20Iо., 83, I47, i LIBUŠE JIRSAK, Ljubo Babić: Dokumenti, vrijeme, galerije. Biblioteka Povijest Moderne galerije, knjiga 3, Zagreb, Moderna galerija, 20II., 34, 42, I34. Dušan Plavšić je naslijedio i značajnu zbirku umjetnina starije umjetnosti o kojoj je pisao Vladimir Lunaček Vidi: VLADIMIR LUNAČEK, Hrvatske privatne zbirke, u: Savremenik, Io (I9I5.), 295-297.

4I Arhiv za likovne umjetnosti HAzU, Rudolf Valdec. Bilješke autora III (iz ostavštine), sign. D.538/3.

42 VLADIMIR LUNAČEK, Prilike i neprilike naše umjetnosti, u: Obzor, 3. 8. 1922., 208.

43 Rudof Valdec (bilj. 4I).

44 HR-HDA-I979, kut. 2, Zapisnik skupštine Društva umjetnosti, 6. ožujka Ig27.

45 Ibidem, I.

46 Ibidem, 2

47 Ibidem. 
prijedlog da članarina konvertira s I.ooo kruna u I.ooo dinara. U raspravu se uključio Oton Iveković s prijedlogom da ,juridičke osobe" trebaju obnoviti svoj prinos svakih deset, namjesto svakih dvadeset godina. Prihvaća se i promjena § 28. „da se u slučaju likvidacije društva njegova imovina ima da preda u vlasništvo grada Zagreba". 48

Apelira se na članove da plate zaostale članarine, a „bilježenje članova voljan je preuzeti član društva g. Anton Ullrich". ${ }^{49}$ Usvojio se i prijedlog slikara Marka Rašice da se vrati nekadašnji naziv „Hrvatsko Društvo Umjetnosti”. 50

$\mathrm{Na}$ toj izbornoj skupštini za predsjednika je izabran Vjekoslav Heinzel, uz objašnjenje „da se u ovim prilikama grad Zagreb zainteresuje više za sudbinu D.U-i, pa drži najpodesnijim da se zamoli načelnik grada Zagreba g. arh. Vjekoslav Heinzel, poznat kao promicatelj naših kulturnih nastojanja, da preuzme vodstvo društva". Potpredsjednik mu je monsinjor Svetozar Rittig, koji I934. postaje predsjednikom. Odbornici su: Vladimir Arko, Janko Barle, Ivo Šrepel, Vojko Schauff, Vladimir Tkalčić, Milovan Hajdinjak, Artur Schneider, Lujo Thaller, Karlo Spiller, Gjuro Dimović, Mirko Breyer, Ivan Meštrović, Robert Frangeš, Marko Rašica, Vladimir Becić, Joza Kljaković, Ljubo Babić, Ferdo Kovačević, Drago Ibler, Menci Clement Crnčić, Stjepan Hribar, Štefan Kalda i Zlatko Šulentić, a revizori dr. Josip Kombol i prof. Anton Jiroušek.

Na kraju izborne skupštine član Milenko Gjurić predlaže da Društvo izda brošuru o radu i zaslugama pokojnog dr. Ise Kršnjavija, a obrazloženi prijedlog zagovaraju osobito predsjednik Dušan Plavšić i Robert Frangeš Mihanović, pa se prijedlog prima. ${ }^{51}$ Time je-dakle s (nezaobilaznim!) Kršnjavijem-zaokružena još jedna etapa u povijesti Društva, premda predložena monografija nije priređena ni objavljena.

U jesen r94I. Plavšić je uhapšen i otpremljen u Staru Gradišku, a s velikim naporom prijatelji ga izvlače iz logora te je dio rata proveo u sanatoriju Merkur. Nakon rata, po Uredbi Saveznog izvršnog vijeća o umjetničkim mirovinama, ukazala se i Plavšiću nada da dobije mirovinu kao književnik, a on se trudio da mu se prizna staž od I. siječnja I898., odnosno od vremena kada je u Beču pokrenuo časopis Mladost. ${ }^{52}$ Nakon Drugoga svjetskog rata Plavšić u visokim kulturnim krugovima nije zaboravljen. Inicijativni odbor za osnutak Društva prijatelja umjetnosti Hrvatske poziva ga na osnivačku sjednicu, na koju su također pozvani Marijan Detoni, tadašnji prorektor Akademije likovnih umjetnosti, Krsto Hegedušić, profesor na Akademiji, akademik Tomislav Krizman, Ivo Režek, predsjednik ULUH-a, dr. Ivan Ribar, predsjednik prezidija Narodne skupštine FNRJ, dr. Svetozar Rittig, predsjednik Savjeta za vjerska pitanja, Ivo Steiner, referent Savjeta za prosvjetu i kulturu NRH, prof. Vladimir Tkalčić, prof. Zdenko Vojnović, direktor Muzeja za umjetnost i obrt, Vanja Žanko, novinar i Drago Magjer, tajnik UNICEF-a za NRH, koji potpisuje poziv u svojstvu tajnika inicijativnog odbora 5 . prosinca I953. godine. ${ }^{53}$

Dušan Plavšić je na koncu života u potpunosti promijenio svoj stav prema Kršnjaviju priznavši mu brojne zasluge, što nam je prenijela Olga Maruševski i o tome ostavila zabilješku u
48 Ibidem, 3 .

49 Ibidem.

50 Ibidem.

5I Ibidem, 4. Kako je razvidno iz citiranog izvještaja, Plavšić je već te, I927. godine, znatno ublažio svoj stav i mišljenje o Kršnjaviju.

52 MIRA KOLAR (bilj. I), I37-I38.

53 HR-HDA-575, Obitelj Plavšić, kut. 4I, dopis na memorandumu Društvo prijatelja umjetnosti Hrvatske, 9 . prosinca 1954. (potpisnici Ivan Ribar i Tomislav Krizman), popis osoba pozvanih na sjednicu inicijativno odbora Društva i nacrt pravila s planom rada („Program”). 
knjizi o historijatu Društva umjetnosti. ${ }^{54}$ Obojica su nastojali pomaknuti granice hrvatske likovnosti potičući umjetnike i njihov rad te gradeći institucionalni okvir galerijskih i muzejskih prostora, zahvaljujući platformi koju je pružalo Društvo umjetnosti.

Autorica je na 4. kongresu hrvatskih povjesničara umjetnosti izlagala pod naslovom „Plavšić smijenio Kršnjavija”-Hrvatsko društvo umjetnosti na prijelomnici I9I8./IgI9. godine u sklopu panela I5o godina djelovanja Hrvatskog društva likounih umjetnika na kojem su sudjelovali: Tamara Bjažić Klarin, Tomislav Buntak, Iva Matija Bitanga, Dalibor Jelavić, Irena Kraševac, Ivana Mance, Ana Šeparović, Robert Šimrak, Petra Šlosel i Josip Zanki.

\section{(ㄷ) (i)}

„Plavšić smijenio Kršnjavija”-Hrvatsko društvo umjetnosti na prijelomnici I9I8./I9I9. godine / Irena Kraševac/ CC BY / 4.o

DOI: https://doi.org/Io.3I664/z4khpu.35
54 OLGA MARUŠEVSKI (bilj. I) 2004., 296, bilj. 22. Plavšic je govorio o Kršnjaviju kao velikom i zaslužnom čovjeku. Sjećanja na taj susret Olga Maruševski podijelila je u razgovoru s autoricom ovog članka, a dio Plavšićeve ostavštine koju je tom prigodom od njega dobila, npr. fotoreprodukcije slika Vlaha Bukovca koje su služile kao priprema za tisak u časopisu Mladost i razglednice Wiener Werkstätte ušle su s njezinom donacijom kao Arhiv Maruševski u Institut za povijest umjetnosti. Djela su reproducirana i u navedenoj knjizi, reprodukcije Bukovčevih djela Studija Klytije, Les ebats, Dalmatinski ribari, Djevojka s cvijetom, str. 224-227, a razglednice Wiener Werkstätte na str. 2I2-2I5. 